\title{
THE RELATIONSHIP BETWEEN INPATIENT CORRIDOR LAYOUT AND THE RISK OF INFECTION TRANSMISSION IN HOSPITAL: A SYSTEMATIC REVIEW
}

\author{
Ratna Agtasari, Amal Chalik Sjaaf \\ Department of Policy and Health Administration, Faculty of Public Health, \\ Universitas Indonesia
}

\begin{abstract}
Background: The physical design of the hospital is an important component of infection control measures to minimize the risk of transmission of infectious diseases. Most hospitals in developing countries are not scientifically designed including wards and corridors. This study aimed to review systematically the relationship of inpatient corridor layout in hospital with risk of infection transmission.

Subjects and Method: A systematic review was conducted by searching published articles from 2010 to 2019, from databases including Scopus, ProQuest, and EBSCO. The keywords were "hospital OR inpatient AND corridor OR hallway OR passageway AND infection or healthcare-associated infection". The inclusion criteria of this study were articles published in the last 10 years, full text, system, and open access. After review process, 9 articles were included in this review.

Results: Two studies examined the effects of corridor shape on hospitals and mapped the distribution of infections. One article was related to aerosol dilution in the inpatient corridor, another related to energy efficiency as an effect of hospital corridor design. Three studies were concerned with infection transmission through the air, another investigated the use of natural ventilation in buildings. One article looked at the latest air system development.

Conclusion: Looped double corridor has a higher risk of spread of infection compared to hybrid and double-loaded corridor. Movement in the looped double corridor is short, so the spread of infection can occur quickly. In addition to the shape of the corridor, the spread of infection in the inpatient room is also influenced by the particular air system used. In double-loaded corridors it is not recommended to apply natural ventilation.
\end{abstract}

Keywords: corridor, hospital, infection, environment

\section{Correspondence:}

Ratna Agtasari. Department of Policy and Health Administration, Faculty of Public Health, Universitas Indonesia, Depok, West Java, Indonesia. Email: ratna.agta@gmail.com. Mobile: o81282063745.

\section{BACKGROUND}

Health Care Associated Infection (HAIs) which are also called "nosocomial" infections or hospital infections are infections that are obtained or arises during the treatment process in a hospital or other health care facility that originally did not exist or was incubated upon admission (Collins, 2009) .

The effect can occur when treated or after discharge. All infections that occur within 48 hours after being treated can be considered as hospital infections (Kim and Kweon, 2018). This problem is very serious because it can cause complications and worsen the patient's condition, so that the patient's length of stay increases and can even cause death. The impact is the costs incurred by patients and hospitals will increase.

HAIs are a big problem faced all over the world and the incidence is increasing. Hundreds of millions of patients are exposed to HAIs around the world each year, causing death and increasing health care costs. According to the data of the WHO, in 2006, the incidence of HAIs in the UK was $9 \%$, it was $6.7 \%$ in Italy in 2005, and 6.7-7.4\% in France in 2006. 
The incidence rate in Indonesia was taken from 10 teaching hospitals that had active surveillance, which is $6-16 \%$ with an average of $9.8 \%$. HAIs themselves are more common in low- and middle-income countries than high-income countries, especially in patients treated in intensive care and neonates (Yankes, 2018). Patients who are treated in the inpatient room, have lower immunity compared to healthy people and bacteria that are resistant to real drugs as a result of treatment.

The Quality Chasm stated that the health care environment must be safe for all patients, in all processes and at all times. This standard requires that the health services provided must be consistent throughout the day, both day and night. The physical environment of a hospital is one of the important factors in health services in a hospital that must be able to prevent its users, especially patients from getting injured, including preventing the spread of infection in the hospital.

The physical environment of the hospital can include good facility design, waste management according to the requirements and a good air system. An inpatient room is a treatment room for patients in a hospital equipped with a corridor between inpatient rooms which is bypassed by doctors, nurses, visitors, other officers and patients have a long period of time. A corridor is a unique function of a hospital space, where air mixing can occur. Retrospective studies found that the patient's room had positive pressure that drained air out, to the surrounding rooms and corridors. Analysis in the nearest inpatient room up to $90 \%$ of the air system is not regulated, it can be negatively pleasing compared to the corridor (Mousavi, 2014). This Systematic review emphasizes the effect of the physical aspects of the building in this case is the form of corridors and air flow in the inpatient room with the risk of spread of infection in the hospital.

\section{SUBJECTS AND METHOD}

\section{Study Design}

This study was a systematic review. The data was obtained from research articles around the world by accessing e-Resources: Scopus, ProQuest, and EBSCO host on page lib.ui.ac.id.

The study was carried out in stages by storing search results with keywords group hospital OR inpatient AND corridor OR hallway OR passageway AND infection OR healthcare-associated infection in each eResources. Search for articles was limited to complete study articles in the period 20102019. 'The keywords were using English, but there were no language restrictions on article search criteria with the consideration that a study related to the theme was very limited.

The study was carried out in stages according to groups of equivalent keywords using "OR" then each result was stored. Then the previous search results were combined with "AND". A search using EBSCO host resulted in 1,314, Scopus yielded 56 , and ProQuest 1,929 totaling 3,299 complete articles. From these results, they were selected based on the title and abstract, producing 11 complete articles relevant to this study. Of the 11 complete articles, there were two duplicate articles so that nine complete articles were included in the systematic review.

\section{RESULTS}

The first study used a Multi-Agent Based Model (MABM), which consisted of an actorbased model that was the actor, the environment in which it occurred and moved and its interaction relationships. If there are two actors, they were called multi-acting agents. 
Table 1. Characteristics of the selected study

\begin{tabular}{|c|c|c|c|c|c|c|c|}
\hline No. & Tittle & $\begin{array}{l}\text { Researcher } \\
\text { (Year) }\end{array}$ & Result & Location & $\begin{array}{l}\text { Design of } \\
\text { the Study }\end{array}$ & $\begin{array}{c}\text { Subject and } \\
\text { Sample }\end{array}$ & Variable \\
\hline 1. & $\begin{array}{l}\text { A Study on The Spatial } \\
\text { Vulnerability of } \\
\text { Spreading the Sources of } \\
\text { Infection in the Inpatient } \\
\text { Units of General } \\
\text { Hospitals }\end{array}$ & Kim (2018) & $\begin{array}{l}\text { Investigate three spatial } \\
\text { factors in hospital inpatient } \\
\text { corridors with the risk of } \\
\text { spreading infection and } \\
\text { providing the best solution } \\
\text { to reduce the risk of } \\
\text { spreading infection }\end{array}$ & $\begin{array}{l}\text { South } \\
\text { Korea }\end{array}$ & Experimental & $\begin{array}{l}\text { Multi-agent } \\
\text { based model }\end{array}$ & $\begin{array}{l}\text { Hospital corridor } \\
\text { users, location } \\
\text { and movement } \\
\text { environment, } \\
\text { interaction } \\
\text { relationships }\end{array}$ \\
\hline 2. & $\begin{array}{l}\text { Numerical Investigation } \\
\text { of Airborne Infection in } \\
\text { Naturally Ventilated } \\
\text { Hospital Wards With } \\
\text { Central-Corridor Type }\end{array}$ & Zhou (2018) & $\begin{array}{l}\text { Developing inpatient ward } \\
\text { designs in the future to } \\
\text { control infections through } \\
\text { the air }\end{array}$ & $\begin{array}{l}\text { Nanjing, } \\
\text { China }\end{array}$ & $\begin{array}{l}\text { Quasi- } \\
\text { experimental }\end{array}$ & $\begin{array}{l}\text { Inpatient room, } \\
\text { room air }\end{array}$ & $\begin{array}{l}\text { Inpatient } \\
\text { corridor, air } \\
\text { movement }\end{array}$ \\
\hline 3. & $\begin{array}{l}\text { Toward An Energy } \\
\text { Efficient Healthcare } \\
\text { Environment: A Case } \\
\text { Study of Hospital } \\
\text { Corridor Design }\end{array}$ & $\begin{array}{l}\text { Mousavi } \\
\text { (2019) }\end{array}$ & $\begin{array}{l}\text { Study the effects of the rate } \\
\text { of air exchange and the } \\
\text { regulation of pressure and } \\
\text { movement of air } \\
\text { contamination in patient } \\
\text { corridors. }\end{array}$ & $\begin{array}{l}\text { Florida, } \\
\text { US }\end{array}$ & Case study & $\begin{array}{l}\text { Patient } \\
\text { corridor, room } \\
\text { air }\end{array}$ & $\begin{array}{l}\text { Patient corridor, } \\
\text { air flow }\end{array}$ \\
\hline 4. & $\begin{array}{l}\text { Transport of Respiratory } \\
\text { Aerosols in Patient } \\
\text { Corridors Subject to A } \\
\text { Directional and Non- } \\
\text { Directional Airflow - A } \\
\text { Case Study }\end{array}$ & $\begin{array}{l}\text { Mousavi } \\
\text { (2014) }\end{array}$ & $\begin{array}{l}\text { Study the effects of the rate } \\
\text { of air exchange and the } \\
\text { regulation of pressure and } \\
\text { movement of air } \\
\text { contamination in patient } \\
\text { corridors. }\end{array}$ & Nebraska & Experimental & $\begin{array}{l}\text { Two corridors } \\
\text { in the hospital } \\
\text { inpatient room, } \\
\text { air room }\end{array}$ & $\begin{array}{l}\text { Particle size, } \\
\text { time and } \\
\text { distance and } \\
\text { source of } \\
\text { infection from } \\
\text { the patient's area }\end{array}$ \\
\hline 5. & $\begin{array}{l}\text { Airflow As A Possible } \\
\text { Transmission Route of } \\
\text { Middle East Respiratory } \\
\text { Syndrome at An Initial } \\
\text { Outbreak Hospital in } \\
\text { Korea }\end{array}$ & Sung (2018) & $\begin{array}{l}\text { Identifying air movement as } \\
\text { a possible route of infection } \\
\text { from secondary infections of } \\
\text { patients whose contacts are } \\
\text { unknown, using spatial } \\
\text { distribution and }\end{array}$ & $\begin{array}{l}\text { South } \\
\text { Korea }\end{array}$ & $\begin{array}{l}\text { Quasi- } \\
\text { experimental }\end{array}$ & $\begin{array}{l}38 \text { patients } \\
\text { with MERS and } \\
\text { inpatient rooms }\end{array}$ & $\begin{array}{l}\text { Patient, inpatient } \\
\text { room }\end{array}$ \\
\hline
\end{tabular}

The $6^{\text {th }}$ International Conference on Public Health Best Western Premier Hotel, Solo, Indonesia, October 23-24, $2019 \mid 489$ https://doi.org/10.26911/the6thicph-FP.04.35 
environmental analysis.

6. A Study of Probable Transmission Routes of MERS CoV During The First Hospital Outbreak in The Republic of South Korea

7. Bioaerosols in Health Care Environment

Grosskoph (2014)

8. Current Trends for Health-Care Ventilation

Ninomura

(2014)

9. Natural Ventilation Use

Xiao (2017)
Grosskoph
(2014)

Li (2013)
Conduct transmission

hypotheses on three main

South

transmissions, namely long-

Korea

range airborne, close

contact and fomite. The risk

of transmission of each

hypothesis is estimated

using a multi agent model

framework.

See how effective directional AS

air flow and the rate of air

exchange to store, merge

and eliminate inhaled

aerosols $(<5 \mu \mathrm{m})$.

installation of air

conditioning systems in

health care facilities

Use of natural ventilation in
Discussion on the technical

\section{Experimental Multi agent \\ method} health care facilities.

\begin{tabular}{|c|c|}
\hline Experimental & $\begin{array}{l}\text { Inpatient } \\
\text { rooms, } \\
\text { isolation } \\
\text { rooms, patient } \\
\text { corridors, room } \\
\text { temperature, } \\
\text { humidity and } \\
\text { air density }\end{array}$ \\
\hline
\end{tabular}

Descriptive

Descriptive
Room

distribution, patient behavior in inpatient rooms, families, visitors, nurses and janitors

Room and air movement

$\mathrm{ACH}$, diffuser, exhaust

Design of health service facilities, patients, officers, visitors, room air quality

The $6^{\text {th }}$ International Conference on Public Health Best Western Premier Hotel, Solo, Indonesia, October 23-24, 2019 | 490

https://doi.org/10.26911/the6thicph-FP.04.35 
This study compared the different forms of corridors in three hospitals, namely Hospital A with hybrid corridor, Hospital B with double-loaded corridor, and Hospital C with double corridor. In Hospital $\mathrm{C}$ that used double corridor, the average frequency of infection exposure was the highest compared to other hospitals. These results were consistent with the visual analysis conducted. Double corridor was most effective in minimizing distance, but also faster in spreading infection.

Tabel 2. Frequency of Infection Exposure

\begin{tabular}{lccc}
\hline \multicolumn{1}{c}{ Hospital } & Hospital A & Hospital B & Hospital C \\
\hline Frequency of average infection & 8.91 & 4.61 & 9.6 \\
Frequency of maximum infection exposure & 44 & 23 & 28 \\
Frequency of minimum infection exposure & 0 & 0 & 0 \\
\hline
\end{tabular}

The second study looked at air movement in inpatient corridors using natural ventilation. Natural ventilation is effective in reducing the spread of infection if the door and window are open so that air exchange can occur properly. However, its movement patterns are very difficult to predict and regulate and cause cross ventilation. Air from higher pressure can flow into rooms with lower air pressure. In China, the use of central-corridor is very commonly used, but there is no minimum ventilation requirement that must be applied.

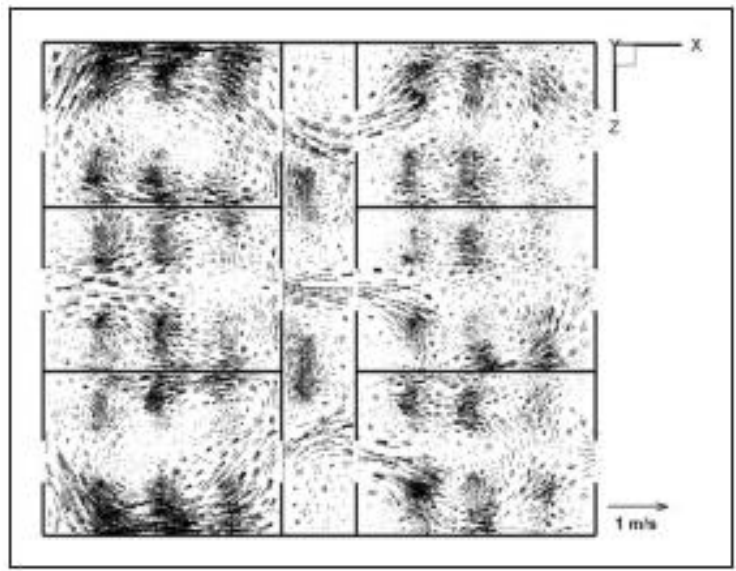

Figure 1. Movement of air in the inpatient room with natural ventilation

The third study emphasized the modification of ventilation in patient corridors. Particles in the corridor can be reduced in ac-cordance with the level of ventilation. The highest particle value at the location of the particle was released and decreases in accordance with the distance. Particles can also be reduced if the air flow is increased. Mentioned in the fourth article, the American Society of Heating, Refrigeration and Air-Conditioning Engineers (ASHRAE) issued a standard in the patient corridor designated as a neutral pres- sure room to prevent pathogens from moving from room to room. However, this also caused the contribution of the patient corridor in some cases of the spread of infection. Two trials were conducted in two patient corridors, one neutral pressure (non-directional), the other negative pressure (inward-directional).

The experiment resulted that the movement of air had an effect on the movement of 1.0-3.0 $\mu \mathrm{m}$ aerosols (bacteria and fungi) rather than $0.5 \mu \mathrm{m}$ aerosols (droplets). 0.5 
$\mu \mathrm{m}$ can diffuse in the air and is difficult to remove from the environment. In $\geq 0.1 \mu \mathrm{m}$ particles, they are more easily contained and removed in the air but can also be integrated into poorly designed ventilation systems.

The experiment was carried out at a Pyeongtaek St. Hospital. Mary's in South Korea involving 38 MERS sufferers. The spread of MERS was through direct contact, but its spread to the room where MERS sufferers do not go through. This can be caused by a room that does not have ventilation, the form of the central corridor and the effect of insulting from outside the room. The sixth study used a multi-agent framework by looking at three main aspects of MERS-CoV transmission, namely long-range airborne, close contact and fomite. The most likely spatial patterns were long-range airborne and close contact. In the long-range airborne scheme, the ones with the highest risk are the rooms with lower pressure.

The seventh study explained that air change per hour $(\mathrm{ACH})$ was not effective in reducing aerosol concentrations in the inpatient room. Increasing $\mathrm{ACH}$ from 2 to $5 \mathrm{ACH}$ only reduces aerosol concentrations $<5 \mu$ (airborne) on average by only $30 \%$. It is the air movement that effectively drains air from the inpatient room to the corridor. In the inpatient corridor, the concentration of aerosol particles measuring $<5 \mu \mathrm{m}$ decreases gradually in line with the distance they travel or at a distance of $25 \mathrm{~m}$. whereas particles of $\geq 5$ $\mu \mathrm{m}$ (droplet) decrease rapidly in line with the distance they travel, which is at a distance of $3 \mathrm{~m}$.

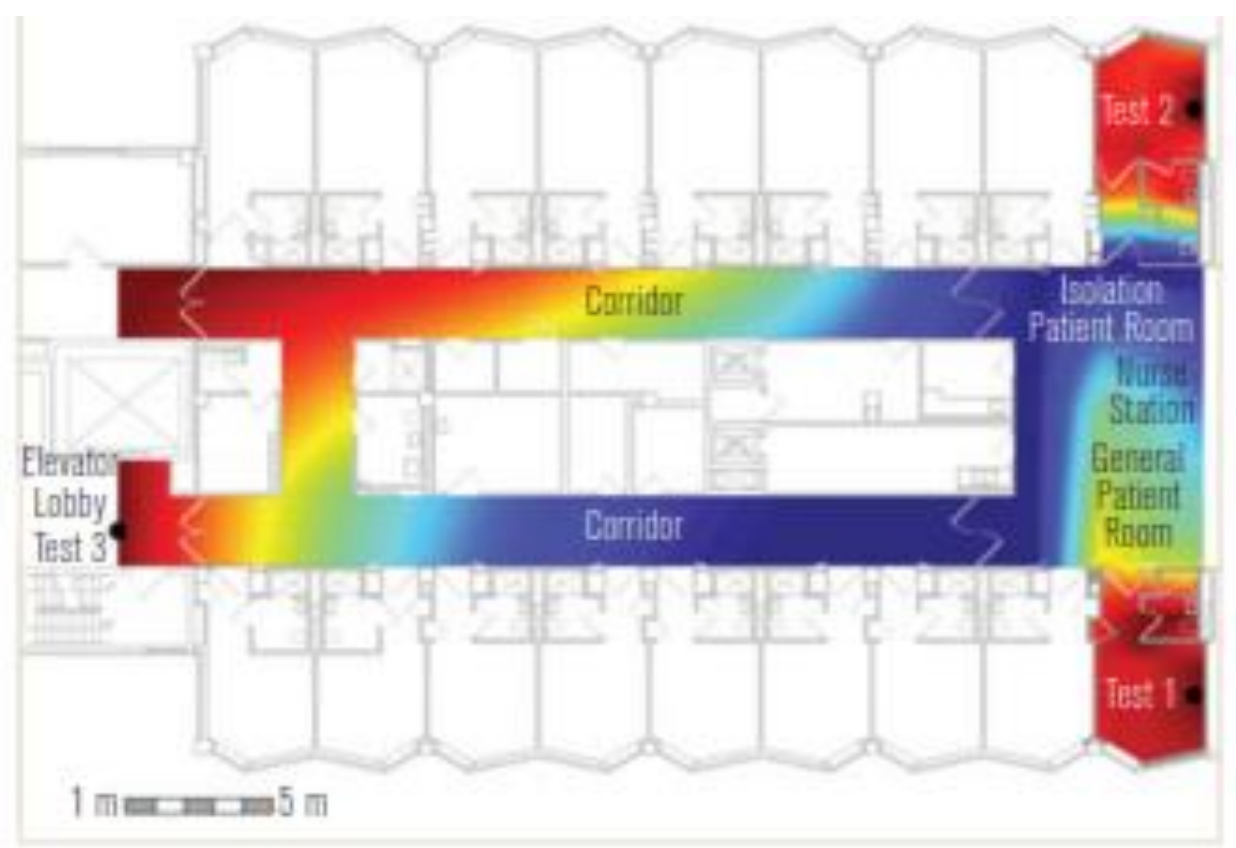

Figure 2. Mapping of air flow in hospital inpatient corridors 
The $8^{\text {th }}$ study described the developments in the air system that can be applied in hospitals. There were parameters that must be met by a room, namely the air pressure of the room (positive or negative), air change per hour $(\mathrm{ACH})$, humidity, temperature, air that is directly released to the outside and air that is circulated. The 9th study described WHO guidelines for the use of natural ventilation in health care facilities. This article describes the basic principles of how to plan, build, operate and maintain an effective natural ventilation system.

\section{DISCUSSION}

From the studies that have been obtained and reviewed, there is a correlation between the forms of the corridor in the inpatient room with the risk of spread of infection in the hospital which is also affected by the air system used.

In the type of central corridor or double-loaded corridor with inpatient rooms that use natural ventilation, the likelihood of infection spread is very high because the rate of air exchange and direction of movement cannot be regulated, especially in rooms that have lower air pressure.

However, in an inpatient room that has an air conditioning arrangement or circulation, not only conditions, the highest risk of infection spread is in the form of looped double corridor, compared to the form of doubleloaded corridor and hybrid corridor. Particle size also affects the movement of aerosols in the corridor. Aerosol concentrations decrease rapidly with respect to distance.

$\mathrm{ACH}$ is not effective in reducing the content of aerosol concentrations in inpatient rooms. An increase in ACH from 2 to 5 only reduces aerosol concentrations $<5 \mu \mathrm{m}$ by an average of 30\%. Effective directional air flow drains air from the inpatient room to the corridor. The existing air conditioning requirements will be effective in dealing with par- ticles in the air when the relationship between air pressure between the room and the position of the door between the inpatient room and the corridor is well maintained.

The movement of the air rate is strongly affected by pressure on the air system in a room. Rooms that have higher air pressure will drain air to rooms that have lower pressure. Hospital corridors are designed to have neutral pressure so that air that flows from the inpatient room does not lead to another room.

Therefore, in the form of a doubleloaded corridor, it is not recommended to apply to inpatients that use natural ventilation, because the air rate and the direction of movement cannot be regulated. Particles $<0.5 \mu \mathrm{m}$ can be well diluted if the air movement is directed and related to the distance. In the double-looped corridor, the distance traveled is short so that the spread of infection can occur faster than the other two forms of corridor.

Hospitals as health service facilities that have a risk of the spread of infection; it should also pay attention to aspects of the physical environment as an effort in preventing the spread of infection. Hospital inpatient corridors, where many users are mixed, can be a source of risk for the spread of infection. The hospital corridor should have been designed with spatial considerations, namely the distance, width and the air system.

\begin{tabular}{l}
\hline REFERENCES \\
\hline Ditjen Yankes (2017). Pencegahan dan \\
Pengendalian Infeksi di RSJS Ma- \\
gelang, Kementerian Kesehatan RI. \\
Retrieved from https://rsjsoerojo.co.id- \\
/2017/o2/24/inhouse-training-ppi- \\
tingkat-dasar-di-rsjs-magelang/ \\
Grosskopf BK, Mousavi E (2014). Bioaerosols \\
in Health-Care Environments.
\end{tabular}

The $6^{\text {th }}$ International Conference on Public Health Best Western Premier Hotel, Solo, Indonesia, October 23-24, 2019| 493 https://doi.org/10.26911/the6thicph-FP.04.35 
Kim SY, Kweon J (2018). A Study on the spatial vulnerability of spreading the sources of infection in the inpatient units of general hospitals', Archives of Design Research, 31(2): pp. 133-152. doi: 10.15187/adr.2018.05.31.2.133.

Li Y (2013). Guideline for infection control: Natural ventilation use, ASHRAE Journal. Retrieved from http://www.wbdg.org/resources/naturalventilation.php.

Mousavi ES, Grosskoph KR (2014). Transport of respiratory aerosols in patient corridors subject to a directional and non-directional airflow - a case study, ASHRAE Annual Conference, 1-10.

Mousavi ES (2019). Toward an energy efficient healthcare environment: a case study of hospital corridor design, International Journal of Environmental Science and Technology. Springer Berlin Heidelberg, (o123456789). doi: 10.1007/s13762-019-02386-4.

Ninomura $P$, Rousseau C, Ninomura $T$ (2014). Current trends for health-care ventilation, ASHRAE Journal, 56(4): $32-42$.
Sung M, Jo S, Lee SE, Ki M, Choi BY, Hong JK (2018). Airflow as a possible transmission route of middle east respiratory syndrome at an initial outbreak hospital in Korea, International Journal of Environmental Research and Public Health, 15(12): 1-11. doi: 10.3390/ijerph15122757.

Wakefield MK (2008). The quality chasm series: Implications for nursing, Patient Safety and Quality: An Evidence-Based Handbook for Nurses, 47-66. Retrieved from http://www.ncbi.nlm.nih.gov/pubmed/21328776.

Xiao S, Li Y, Sung M, Wei J, Yang Z (2018). A study of the probable transmission routes of MERS-CoV during the first hospital outbreak in the Republic of Korea, Indoor Air, 28(1): 51-63. doi: 10.1111/ina.12430.

Zhou Q, Qian H, Liu L (2018). 'Numerical investigation of airborne infection in naturally ventilated hospital wards with central-corridor type', Indoor and Built Environment, 27(1): 59-69. doi: 10.1$177 / 1420326 \mathrm{X} 1666177$ 